\title{
MODEL LANSKAP PERMAKULTURA KEBUN PERCOBAAN CIKABAYAN UNTUK MEMENUHI KEBUTUHAN PANGAN BERGIZI MAHASISWA ASRAMA IPB
}

\author{
Model of Cikabayan Permaculture for \\ Fulfilling Nutritious Food Needs \\ IPB's Dormitory Students
}

\section{Rizka Nabilah \\ Mahasiswa Sekolah Pascasarjana IPB, Program Studi Arsitektur Lanskap \\ Email : rzknabilah@gmail.com \\ Wahju Qamara Mugnisjah \\ Staf Pengajar Departemen Arsitektur Lanskap, Fakultas Pertanian IPB}

\section{Andi Gunawan}

Staf Pengajar Departemen Arsitektur Lanskap, Fakultas Pertanian IPB

\begin{abstract}
The food quality is determined by the food system, from the food production process, food distribution to food consumption. The production process is related to the agricultural landscape planning. That is the most important step to contribute the production results. Yet, basic knowledge about its benefits values for increasing the potential production are unknown, hence people usually ignore this step planning. Bogor Agricultural University (IPB) as the center of excellence of agricultural science and technology can be a potential sample for application of agricultural planning for production. Thus, the concept of permaculture, which is linked by agricultural productivity based on socio-economic, and ecological has a big chance to be applied. The general objectives of this research were to compose permaculture landscape model and for supply nutritious food needs IPB's dormitory students. The research surveyed bio-physics potency in Cikabayan campus experimental sites. These estimations are really useful for site analysis of model of permaculture. Result showed the nutritious food needs ingredients for IPB's dormitory students is 2299.14 tons from source of plant foods and 406.35 tons from source of animal food which is divided into 18 commodities. The results of agricultural planning with the permaculture landscape model at Cikabayan experimental sites. Results showed that there is a potential production corn 28.43 tons, spinach 10.89 tons, tomato 22.348 tons, kale 6.54 tons, bean 16.44 tons, celery 3.92 tons, and spring onion 5.6 tons. Totally production to supply food needs plant about 94.168 tons. These productions results from Cikabayan experimental sites can supply about food needs plant resources $4.09 \%$ for IPB's dormitory students. This approach could be used by local campus institution to created food self-sufficiency from the assets of land.
\end{abstract}

Keywords: agriculture landscape, permaculture, nutritious food, a student dormitory IPB

\section{PENDAHULUAN}

Institut Pertanian Bogor (IPB) merupakan salah satu perguruan tinggi yang memiliki konsep pembinaan bagi mahasiswa yaitu dengan menyediakan asrama untuk mahasiswa tingkat persiapan bersama (TPB). Tujuan pendirian asrama yaitu sebagai tempat pembinaan mahasiswa yang bersifat akademis, multibudaya, dan adaptasi dengan lingkungan IPB (Soekarno et al.,). Namun, terdapat data yang menunjukkan bahwa terdapat $12.5 \%$ mahasiswa yang berstatus gizi kurus sekali dan 23\% mahasiswa berstatus kurus, diduga karena tidak seimbangnya antara aktivitas dan konsumsi pangan mahasiswa (Priandono 2006). Menurut World Health Organization (WHO) tahun 2007, faktor risiko umum penyakit adalah pola konsumsi makanan yang tidak sehat (unhealthy diet). Dengan demikian, perlu pertimbangan mengenai penyediaan bahan pangan serta prosesnya hingga siap di konsumsi.

Penyediaan bahan pangan dengan kualitas yang baik menjadikan mahasiswa sehat sehingga dapat mendukung seluruh aktivitasnya dengan optimal (Almatsier 2005). Proses konsumsi berawal dari penyediaan bahan mentah, yang berkaitan dengan hasil produk pertanian. Pertimbangan mengenai penyediaan pangan yang berkualitas, sangat berpengaruh dari proses produk pertanian yang berkualitas pula (Holmgreen 2006).

IPB sebagai center of excellence dalam pengembangan ilmu pengetahuan dan teknologi pertanian dapat berpotensi sebagai contoh atau role model untuk produksi pertanian. Salah satu keuntungan penyediaan pangan secara mandiri adalah terjaminnya produk dengan kualitas yang baik. Selanjutnya, pengelolaan yang benar pada produk mentah dapat menjamin status gizi bahan pangan yang dihasilkan.

IPB memiliki fasilitas pendukung kegiatan kampus untuk melaksanakan tridharma perguruan tinggi (Soekarno 2011). Fasilitas untuk menunjang tridharma perguruan tinggi yang berkaitan dengan pendidikan dan penelitian yaitu adanya laboratorium lapang University Farm (UF IPB) yang meliputi kebun percobaan, kolam, laboratorium laut, ladang penggembalaan ternak, dan hutan pendidikan. Selain itu, IPB memiliki kerja sama dengan desa-desa lingkar kampus IPB sebagai bentuk pengabdian kepada 
masyarakat. Oleh karena itu, model lanskap permakultur dapat dilakukan di beberapa unit kebun percobaan dan desa-desa lingkar kampus IPB sebagai bentuk pemberdayaan aset untuk memenuhi kewajiban tridharma perguruan tinggi.

Tujuan penelitian adalah sebagai sebagai berikut:

1. mengidentifikasi kebutuhan pangan dan gizi mahasiswa asrama IPB;

2. mengidentifikasi potensi pertanian di Kebun Percobaan Cikabayan IPB;

3. menganalisis kecukupan pangan dan gizi mahasiswa asrama IPB berdasarkan potensi pertanian di Kebun Percobaan Cikabayan IPB;

menyusun model lanskap permakultura untuk memenuhi kebutuhan pangan dan gizi mahasiswa asrama IPB.

\section{METODOLOGI}

\section{Lokasi dan Waktu Penelitian}

Penelitian dilakukan di Kebun Percobaan Cikabayan di Kecamatan Dramaga Kabupaten Bogor (Gambar 1). Penelitian dilakukan dengan metode kombinasi untuk mengumpulkan data kuantitatif dan kualitatif. Data kuantitatif dilakukan sebagai bentuk pengumpulan data lapang dan data kualitatif didapatkan dari telusur pustaka. Perencanaan model lanskap permakultura dilakukan dengan metode Gold (1980). Metode perencanaan tersebut dimulai dari pra-peneliian, inventarisasi, analisis, dan sintesis.

Data kuantitatif didapatkan dari penyebaran kuisioner terkait dengan data kebutuhan pangan di asrama mahasiswa IPB. Selanjutnya, data kuantitatif berdasarkan data lapang yang berkaitan dengan luasan lahan dan keberadaan vegetasi di Kebun Percobaan Cikabayan.

\section{Alat dan Bahan}

Alat yang digunakan terbagi menjadi dua, yaitu alat dari perangkat keras dan lunak. Perangkat keras yang digunakan adalah lembar survei, lembar kuisioner, perekam suara, Kamera digital, dan Global Positioning System (GPS). Perangkat lunak yang digunakan adalah CAD, ArcMap 10.4, Microsoft Office 2010, Adobe, Google Earth Pro. Bahan yang digunakan dalam penelitian ini yaitu peta kebun percobaan IPB, peta data fisik Kecamatan Dramaga Kabupaten Bogor (Gambar 1).

\section{Metode Analisis Data}

Analisis yang dilakukan meliputi analisis status gizi dan kebutuhannya, analisis komoditi pertanian yang dibutuhkan, dan analisis potensi bio-fisik serta perencanaan lanskap permakultura.

1. Data Status gizi

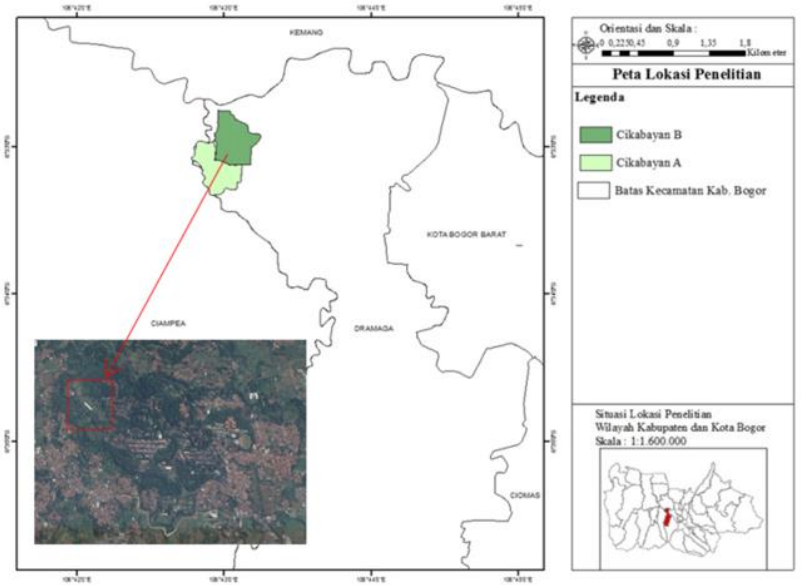

Gambar 1. Lokasi Penelitian

Analisis status gizi dilakukan dengan penelitian langsung, dengan cara penyebaran kuisioner kepada 50 mahasiswa putra dan putri. Data status gizi didapatkan dari pengukuran berat badan dan tinggi badan. Selain itu, dilakukan pertanyaan mengenai preferensi terhadap pengelolaan makanan, mulai dari produk mentah hingga pengelolaan makanan hingga tahap konsumsi. Analisis status gizi ini berdasarkan data yang diambil berupa identitas responden yang meliputi jenis kelamin, tinggi badan, umur, dan jenis aktivitas fisik yang ditabulasikan, selanjutnya dianalisis secara deskriptif. Penetapan status gizi ini berdasarkan $\mathrm{FAO} / \mathrm{WHO} / \mathrm{UNU}$ (1985).

2. Data kebutuhan Pangan

Data kebutuhan pangan dilakukan dengan cara telusr pustaka berdasarkan (Priandono 2006). Terdapat pendekatan asumsi untuk analisis kebutuhan pangan ini. Asumsi-asumsi tersebut didekati dengan faktorfaktor sebagai berikut:

a. jumlah mahasiswa asrama IPB adalah 3500 orang mahasiswa putra dan putri;

b. kebutuhan pangan dan gizi mahasiswa asrama IPB angkatan 52;

c. menu makan dalam satu hari mahasiswa asrama putra dan putri sama dengan data tahun 2006;

d. konversi menu makanan ke dalam komoditas pertanian sama dengan data tahun 2006;

3. Analisis Bio-Fisik Kebun Percobaan IPB dan Desa Cikarawang

Analisisk bio-fisik dilakukan setelah inventarisasi data. Mengelompokkan data yang penting untuk kemudian dianalisis lebih lanjut. Analisis dalam penelitian ini, dibahas beberapa kondisi fisik dan biofisik yang terdapat dalam lokasi penelitian, antara lain: batas tapak dan geografi, iklim, jenis tanah, topografi, curah hujan, vegetasi, satwa, fasilitas dan aksesibilitas. Terdapat 
beberapa aspek fisik yang dipetakan berdasarkan data lapang dan data dari telusur pustaka.

4. Analisis Pola Tanam

Pola tanam, diketahui dari wawancara dan telusur pustaka berkaitan dengan pola tanam yang diterapakan pada masing-masing komoditas pertanian. Dengan demikian, keseluruhan informasi mengenai data topografi, tipe tanah, iklim, curah hujan, komoditas, dan analisis kesesuaian lahan digunakan dalam analisis pola tanam. Hal ini menjadikan terlihatnya rotasi tanaman yang ditanam dan prediksi waktu produksinya. Dengan demikian, dapat diketahui waktu suplay ke asrama mahasiswa IPB.

5. Analisis Perencanaan Lanskap Permakultura

Analisis dari keseluruhan data yang diperoleh kemudian di analisis menggunakan metode campuran. Metode yang menggabungkan beberapa metode dalam suatu fenomena (Denzin 1978). Penggunaan metode ini untuk mencari objek yang sama dari sudut pengambilan data yang berbeda Pahl-Wostl dan Rabbit (2004). Metode penggabungan dengan dua pendekatan metodologis dan materi penelitian (kuantitatif dan kualitatif dengan informasi lokal). Metode campuran menghasilkan pengetahuan gabungan, yaitu muncul melalui integrasi berbagai jenis informasi dan atau melalui multi-, antar, atau trans penelitian -disiplin (Raymond et al., 2010). Hal ini sesuai untuk penelitian lanskap, karena berkaitan dengan narasi (kualitatif) dan data lapang (kuantitatif) (Studer et al., 1998). Selain itu, analisis lanskap mempertimbangkan mengenai beberapa skenario yang memerlukan data kualitatif (Alcamo 2008). Hal ini membutuhkan alat dan metode khusus sebagai pedoman untuk menentukan aturan keputusan dan variabel deskriptif yang digunakan. Hasil analisis seluruh data ini diwujudkan dalam pemetaan dengan bentuk zonasi ruang. Kemudian dilakukan penyesuaian data yang diperoleh dari pengamatan lapang, sehingga didapatkan hasil perencanaan model lanskap permakultura.

\section{HASIL DAN PEMBAHASAN}

\section{Gambaran Umum Lokasi Penelitian}

Kebun percobaan Cikabayan terletak pada 6033'5.55"S lintang selatan dan $106^{\circ} 42^{\prime} 55.35^{\prime \prime} \mathrm{T}$ garis bujur timur. Letaknya relatif dekat dengan lingkungan kampus IPB, dengan jarak kebun percobaan dengan asrama putri adalah $1.42 \mathrm{~km}$. Kebun ini memiliki luasan yang paling luas dari kebun percobaan lainnya. Daerah Cikabayan memiliki luas \pm 22 ha dengan lahan efektif seluas \pm 5 ha. Kebun Percobaan Cikabayan adalah salah satu kebun percobaan yang dikembangkan oleh IPB antara lain program yang dikembangkan adalah Integrated Farming System (Sistem Pertanian Terpadu). Dalam pengolahan lahan Cikabayan juga digunakan teknologi pertanian seperti penggunaan bajak, traktor, pencacah kompos dan pengembangan tanaman hidroponik.

\section{Analisis Status Gizi}

Kebutuhan energi seseorang dalam sehari dapat ditaksir dari kebutuhan energi melalui Angka Metabolik Basal (AMB) yang dianalisis dari peubah berat badan atau tinggi badan. Dalam hal ini, penaksiran dilakukan dengan menggunakan peubah berat badan. Komponen kebutuhan energi berbeda untuk tiap orangnya berdasarkan umur, jenis kelamin, ukuran tubuh, dan tingkat kesehatan. Hasil menunjukkan bahwa nilai AMB dari mahasiswa yaitu $1352.95 \mathrm{kkal} /$ hari dan mahasiswi $1273.75 \mathrm{kkal} /$ hari dengan rata-rata kalori sebesar 1 $313.35 \mathrm{kkal} /$ hari (Tebel 8). Sedangkan, dari perhitungan kebutuhan kalori per hari didapatkan hasil untuk lakilaki 2410 kkal dan perempuan sebesar 2311 kkal dengan perolehan rata-rata keselurihan antara laki-laki dan perempuan adalah $2360 \mathrm{kkal}$ (Tabel 1).

Tabel 1 Kebutuhan kalori mahasiswa asrama IPB

\begin{tabular}{llc}
\hline Peubah & Kalori & $\begin{array}{c}\text { Rata-rata } \\
\text { kalori }\end{array}$ \\
\hline AMB (kkal/hari) : & & \\
a. Laki-laki & 1352.95 & 1313.35 \\
b. Perempuan & 1273.75 & \\
\hline $\begin{array}{l}\text { Kebutuhan kalori } \\
\text { (kkal): }\end{array}$ & & \\
$\begin{array}{l}\text { a. Laki-laki } \\
\text { b. Perempuan }\end{array}$ & 2410 & 2360 \\
\hline
\end{tabular}

Hasil pengamatan terhadap 25 orang mahasiswa putra dan 25 orang mahasiswa putri menunjukkan bahwa IMT tertinggi sebesar $64 \%$ masuk kedalam kategori normal, sedangkan IMT dengan persentase paling rendah $2 \%$ masuk kedalam kategori mahasiswa gemuk sekali. Hal ini menunjukkan sebaran hasil IMT normal pada keselurhuan sampel yang diamati, namun terdapat persentase yang perlu diperhatikan yaitu terdapat $24 \%$ mahasiswa masuk kedalam kategori kurus yang merupakan persentase terbesar kedua setelah angka persentase IMT normal.

Analisis Kebutuhan Pangan dari komoditi pertanian Kebutuhan pangan untuk mahasiswa asrama IPB terdiri dari kebutuhan pangan nabati dan hewani. Komoditi yang menjadi prioritas kebutuhan pangan nabati adalah 
padi, kedelai, jagung manis, pepaya, kangkung, cabai, bayam, buncis, tomat, kentang, wortel, kol, daun bawang, seledri. Pangan hewani yang dibutuhkan adalah susu sapi. ayam, telur ayam, ikan mas (Priandono 2006). Kebutuhan per hari untuk 3500 mahasiswa asrama IPB adalah beras $2153 \mathrm{~kg}$, kentang $525 \mathrm{~kg}$, wortel $525 \mathrm{~kg}$, kol $350 \mathrm{~kg}$, daun bawang $140 \mathrm{~kg}$, seledri $52.5 \mathrm{~kg}$, kedelai $475 \mathrm{~kg}$, jagung $450 \mathrm{~kg}$, pepaya $350 \mathrm{~kg}$, ayam pedaging $210 \mathrm{~kg}$, kangkung $350 \mathrm{~kg}$, cabai $3.5 \mathrm{~kg}$, bayam $350 \mathrm{~kg}$, buncis $262.5 \mathrm{~kg}$, tomat $350 \mathrm{~kg}$, telur ayam 3500 butir, ikan mas $350 \mathrm{~kg}$ dan susu sapi 350 liter (Tabel 2) (Priandono 2006). tertinggi pada tahun 2012 terjadi pada Bulan Februari dengan persentase $87 \%$, sedangkan kelembaban terendah terjadi pada Bulan Agustus dengan persentase 74\%. Kelembaban udara tertinggi pada tahun 2013 terjadi pasa Bulan Januari mencapai $88 \%$ serta angka terendah $78 \%$ pada Bulan September dan November. Tahun 2014 pada Bulan Januari menjadi bulan dengan kelembaban udara tertinggi hingga mencapai $89.5 \%$ dan terendah pada Bulan September dengan persentase $72.6 \%$. Kelembaban udara tertinggi pada tahun 2015 terjadi pada bulan $87 \%$ dan kelembaban terendah pada Bulan September dengan angka 68\%. Rata-rata kelembaban udara dari tahun 2012 hingga 2015

Tabel 2. Kebutuhan bahan pangan untuk mahassiswa asrama IPB

\begin{tabular}{lllllll}
\hline No. & Jenis Pangan & $\begin{array}{l}\text { Kebutuhan } \\
\text { per Porsi }\end{array}$ & Satuan & Konversi & $\begin{array}{l}\text { Kebutuhan per } \\
\text { Hari } \\
\left.(3500 \text { orang })^{5}\right)\end{array}$ & $\begin{array}{l}\text { Luas Lahan yang } \\
\text { Dibutuhkan } \\
(\mathrm{m} 2 / \text { daur })^{6}\end{array}$ \\
\hline 1 & Beras $^{3)}$ & 400 & gram & Padi & 2153 & 583000 \\
2 & Tempe $^{4)}$ & 25 & gram & Kedelai & 175 & 320800 \\
3 & Tahu $^{4}$ & 25 & gram & Kedelai & 350 & 96250 \\
4 & Jagung manis & 150 & gram & Jagung manis & 450 & 64200 \\
5 & Pepaya & 100 & gram & Buah pepaya & 350 & 560 \\
6 & Daging ayam & 60 & gram & Ayam pedaging & 210 & 14000 \\
7 & Kangkung & 100 & gram & Kangkung & 350 & 420 \\
8 & Cabai & 1 & gram & Cabai merah & 3.5 & 21000 \\
9 & Bayam & 100 & gram & Bayam & 350 & 47800 \\
10 & Buncis & 75 & gram & Buncis & 262.5 & 39700 \\
11 & Tomat & 100 & gram & Tomat & 350 & 280 \\
12 & Telur ayam & 1 & buah & Telur ayam & $\left.3500^{1}\right)$ & 10 \\
13 & Ikan mas & 100 & gram & Ikan mas & 350 & - \\
14 & Kentang & 150 & gram & Kentang & 525 & - \\
15 & Wortel & 150 & gram & Wortel & 525 & - \\
16 & Kol & 100 & gram & Kol & 350 & 5.6 \\
17 & Daun bawang & 40 & gram & Daun bawang & 140 & 10.5 \\
18 & Seledri & 15 & gram & Seledri & 52.5 & 350 \\
19 & Susu sapi & 100 & ml & Susu sapi & $\left.350^{2}\right)$ & 11880361 \\
\hline & & & Jumlah & 6386.5 & \\
\hline
\end{tabular}

Sumber : (Priandono 2006) dengan modifikasi
Keterangan : ${ }^{1}$ ) butir
4) $1 \mathrm{~kg}$ tempe $=2 \mathrm{~kg}$ kedelai
$\left.{ }^{2}\right)$ liter
5) kebutuhan total untuk 3500 mahasiswa per hari
3) rendemen beras giling $=65 \%$
6) luas lahan inimenjadi rujukan perencanaan permakultura

\section{Analisis Potensi Bio-Fisik Kebun Percobaan Ciakbayan}

Rata-rata suhu tertinggi yang diamati berdasarkan bulan, pada tahun 2012 hingga 2015 tercatat pada Bulan Mei memiliki suhu tertinggi dengan angka $26.67{ }^{\circ} \mathrm{C}$. Kecamatan ini terletak di bagian barat kota, tepatnya sekitar $8 \mathrm{~km}$ dari pusat kota Bogor. Kelembaban udara menunjukkan bahwa angka tertinggi persentase kelembaban udara terjadi pada Bulan Januari $87.62 \%$ dan rata-rata kelembaban terendah terjadi pada bulan September dengan persentase $73.65 \%$.

Curah hujan yang terdapat di Kecamatan Dramaga tergolong tinggi sekali pada bagian Utara Wilayah Dramaga yaitu +5 $000 \mathrm{~mm}$. sedangkan, pada bagian 
lainnya tergolong tinggi dengan nilai yang beragam. Pada bagian tengah tergolong memiliki curah hujan tinggi dengan nilai 3 500-4 $000 \mathrm{~mm}$. Pada bagian selatan memiliki curah hujan yang tergolong timggi pula dengan nilai 3 000-3 $500 \mathrm{~mm}$. Hasil suatu jenis tanaman bergantung pada interaksi antara faktor genetik dan faktor lingkungan seperti jenis tanah, topografi, pengelolaan pola iklim dan teknologi. Wilayah dengan kondisi iklim tertentu akan didominasi iklim tertentu akan didominasi pula oleh spesies tumbuhan tertentu, yakni tumbuhan yang dapat beradaptasi secara baik pada kondisi iklim tersebut (Lakitan 2002).

Kebun percobaan Cikabayan ini memiliki potensi untuk dikembangkan menjadi model lanskap permakultura. Kebun produksi Cikabayan direncanakan terdiri dari empat blok, yaitu blok D1, D2, D3, dan D4 (Gambar 2). Pada masing-masing blok memiliki perbedaan luasan, luas blok D1 adalah 0.8 ha, luas blok D2 adalah 0.25 ha, luas blok D3 adalah 0.48 dan luas blok D4 adalah 0.56 ha. Perencanaan penanaman untuk vegetasi pembatas di bibir lahan dengan penggunaan vegetasi Leucaena leucocephala (lamtoro), Albizia chinensis (sengon) dan Nephelium lappaceum (rambutan). Kebun produksi ini telah memiliki sistem penerimaan pupuk kandang dari lokasi laboratorium lapang fakultas peternakan yang ada di dekat lokasi ini. Selain itu, tanaman lokal lain yang direncanakan berpotensi sebagai pengendali hama pada lokasi ini antara lain tembelekan (Lantana camara), cocok botol (Tagetes erecta), dan bandotan (Ageratum conyzoides). mengetahui hasil produksinya per tahun. Hasil produksi untuk Kebun Cikabayan ini pada tahun pertama adalah kedelai 6.54 ton, jagung 28.431 ton, kangkung 13.132 ton, bayam 10.89 ton, buncis 16.44 ton, tomat 22.348 ton, bawang daun 5.6 ton, dan seledri 3.92 ton.

\subsection{Perencanaan Lanskap Permakultura}

Sistem pertanian yang selama ini diusahakan masyarakat Indonesia secara konvensional telah mengalami kemunduan, bahkan cenderung merusak lingkungannya (Sudaryanto \& Eishener 2003). Praktik permakultura merupakan praktek pertanian berkelanjutan untuk pertanian, perkebunan, dan peternakan. Dalam praktik permakultura memiliki konsep integrasi antara tanaman, hewan, manusia, dan lanskap ke dalam sistem simbiosis produk dari satu elemen dapat memenuhi kebutuhan lainnya. (Morrow, 1993). Sebuah perencanaan untukpermakultura dengan basis sains yang dihasilkan dari observasi alam dan pola alam, dengan sebuah perpaduan sains dan seni.

Konsep sistem produksi pada tapak ini didasarkan pada konsep model permakultura atau konsep pertanian yang permanen dengan tujuan berkelanjutan. Permakultura memiliki konsep yang memiliki sistem yang saling berhubungan dalam sistem itu sendiri untuk memenuhi efektivitas dan efisiensi penggunaan energi yang ada. Etika dari konsep permakultura ini yaitu peduli terhadap lingkungan, manusia, surplus distribusi, dan mereduksi konsumsi. Penerapan konsep permakultura di Kebun Percobaan Cikabayan meliputi pertimbangan

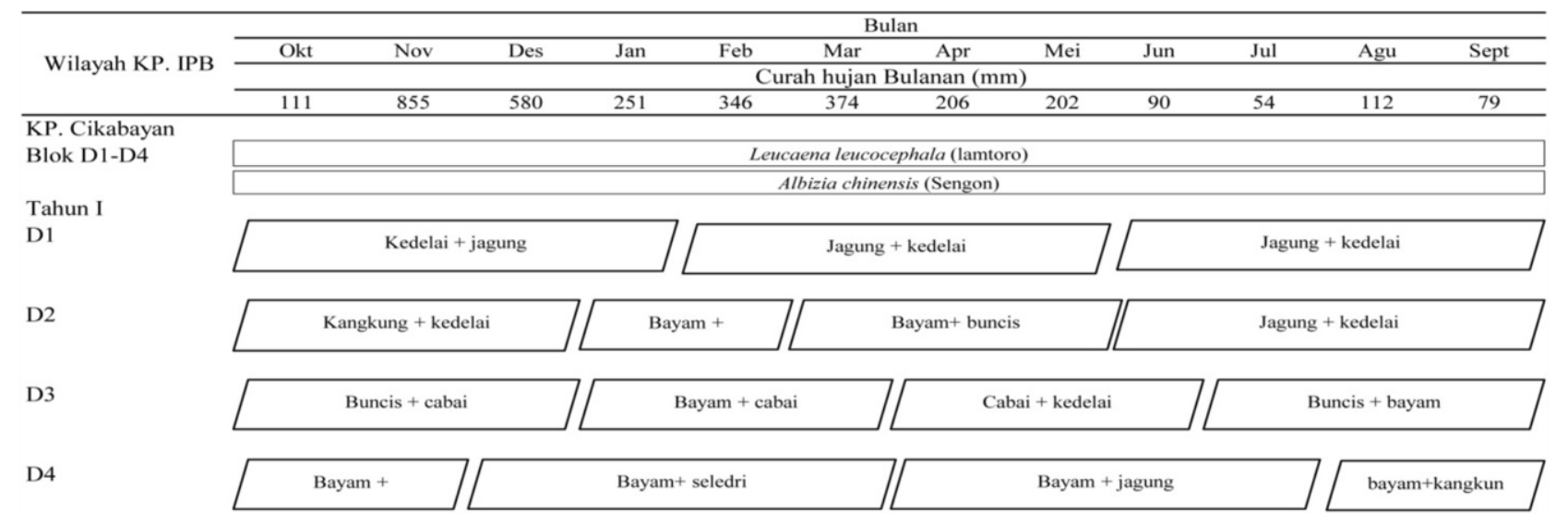

Gambar 2 Rencana Pola Tanam Kebun Cikabayan

Blok D1 direncanakan untuk penanaman kedelai, jagung, dan kedelai. Pada blok D2 di tahun pertama direncanakan kangkung, bayam, jagung, kedelai dan buncis. Pada blok D3 di tahun pertama akan direncanakan penanaman buncis, bayam dan tomat. Pada blok D4 di tahun pertama akan direncanakan penanaman bawang daun dan bayam. Keseluruhan hasil produksi di akumulasi pada masing-masing blok untuk tanaman pertanian yang utama dan tanaman pendukung di sekitar lahan pertanian. Lahan pertanian yang diusahakan memiliki 4 rencana blok yaitu D1, D2, D3, dan D4 (Gambar 3). Hal tersebut dimaksudkan untuk memberikan keanekaragaman tanman yang diusahakan. Selain itu, diusahakan pula kolam ikan sebagai pendukung kebutuhan pangan hewani. Konsep kolam ini berintegrasi dengan tanaman pertanian dalam 


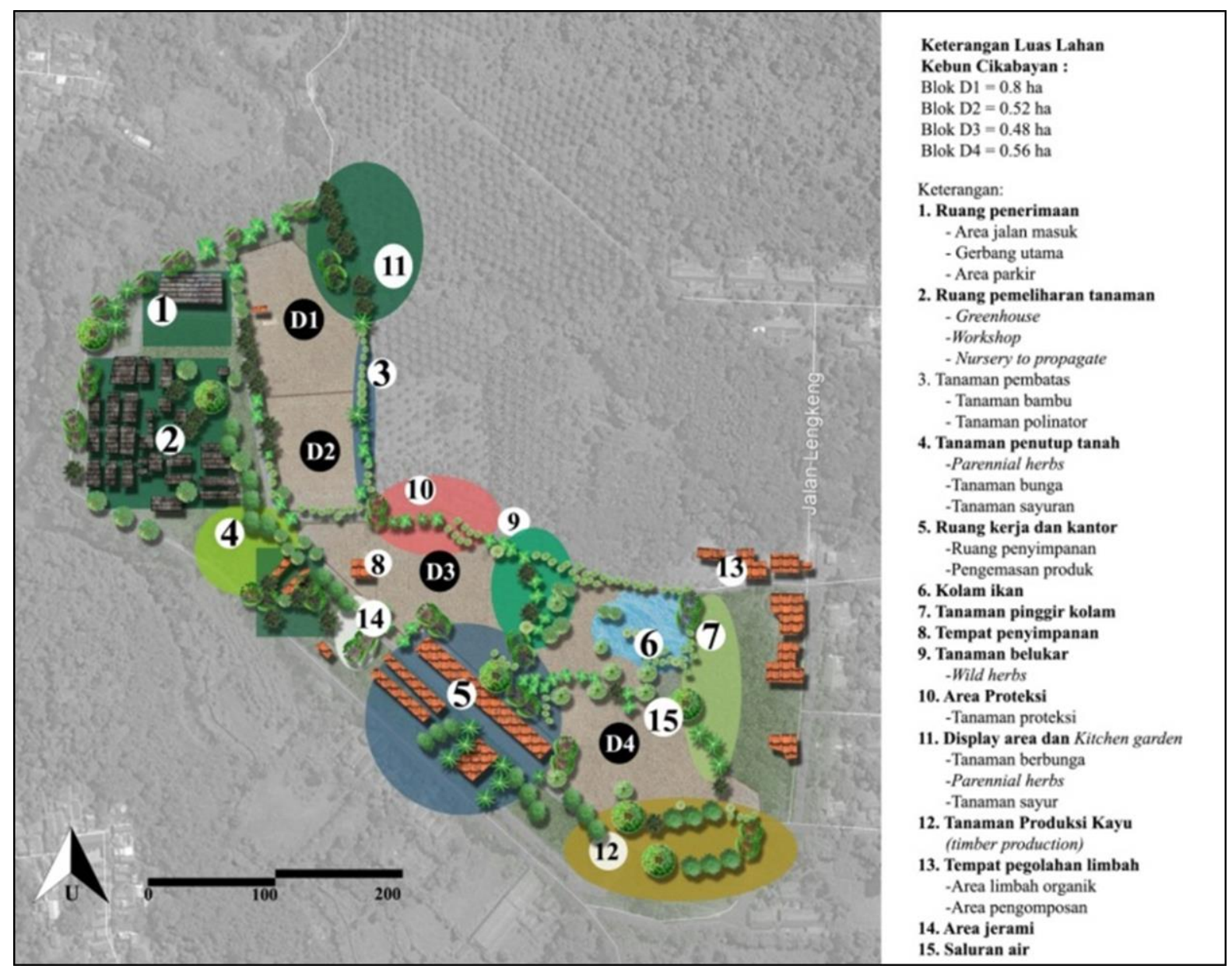

Gambar 3. Perencanaan Lanskap Permakultura Kebun Cikabayan

hal pengelolaan limbah. Limbah yang terdapat di kolam dapat dijadikan sumber yang baik untuk tanaman. Selain itu, tanaman pinggiran yang dipilih untuk kolam dapat dipergunakan untuk mendukung pakan alami ikan. Faktor yang sangat berpengaruh dalam perencanaan lanskap permakultura adalah iklim mikro dan makro, bentukan lahan, air, vegetasi dan hewan, bangunan dan infrastruktur, zonasi, penggunaan lahan, tanah berikut fertilitas dan pengelolaannya, dan estetika. Sistem permakultura dapat diterapkan menggunakan bahan, energi, dan tenaga kerja yang minimal. Dengan cara daur ulang, sumber dapat kembali ke dalam sistem serta meminimalkan polusi (Mollison 1993).

\section{SIMPULAN}

Kebutuhan rata-rata kalori mahasiswa asrama putra dan putri IPB berdasarkan angka metabolik basal adalah 1 313.35 kkal/hari. Kebutuhan kalori untuk laki-laki dan perempuan berbeda berdasarkan angka metabolik dasarnya. Laki-laki memiliki kebutuhan kalori berdasarkan angka metabolik dasarnya yaitu 1352.95 kkal/hari, sedangkan mahasiswa putri 1273.75 kkal/hari. Kebutuhan rata-rata kalori dari mahasiswa putra dan putri adalah $2360 \mathrm{kkal}$, dengan rincian mahasiswa putra $2410 \mathrm{kkal}$ dan mahasiswa putri 2311 kkal. Status gizi ddari mahasiswa asrama IPB paling tinggi berstatus normal dengan persentase $64 \%$, berstatus kurus $24 \%$, gemuk $4 \%$ dan gemuk sekali $2 \%$. Kebutuhan bahan pangan untuk mahasiswa asrama IPB adalah 2 299,14 kkal untuk sumber pangan nabati dan 406.35 ton untuk sumber pangan hewani. Kebutuhan pangan tersebut dipenuhi dari beberapa komoditas pertanian. Sumber pangan nabati dan hewani tersebut diketahui didapatkan dari 18 komoditas pertanian. Sumber pangan nabati terdiri dari 14 komoditas pertanian, yaitu beras, kedelai, jagung, pepaya kangkung, cabai, bayam, buncis, tomat, bawang daun, kentang, wortel, kol dan seledri. Sedangkan, untuk sumber pangan hewani didapatkan dari 4 komoditas pertanian, yaitu susu sapi, telur ayam, ikan mas, dan daging ayam. Kebutuhan pangan tersebut menjadi 
acuan untuk merencanakan model lanskap permakultura.

Komoditas pertanian yang direncanakan untuk model permakultura adalah komoditas dataran rendah dan komoditas yang memang sudah diusahakan di wilayah penelitian. Terdapat hanya 11 komoditas untuk sumber bahan pangan nabati, karena terdapat kebutuhan pangan dari komoditas dataran tinggi. Sehingga, komoditas pertanian kol, wortel, dan kentang menjadi komoditas yang tidak dimasukkan ke dalam perancangan model permakultura. Kebun Cikabayan ini pada tahun pertama adalah kedelai 6.54 ton, jagung 28.431 ton, kangkung 13.132 ton, bayam 10.89 ton, buncis 16.44 ton, tomat 22.348 ton, bawang daun 5.6 ton, dan seledri 3.92 ton. Artinya, Kebun Cikabayan dapat menjadi lokasi suplay sumber pangan nabati sebesar 4.09\% untuk mahasiswa asrama IPB.

\section{DAFTAR PUSTAKA}

Alcamo J. 2008. The SAS approach: combining qualitative and quantitative knowledge in environmental scenarios. Environmental Futures: The Practice of Environmental Scenario Analysis. Amsterdam, (NED) pp.123-148.

Almatsier S. 2005. Prinsip Dasar Ilmu Gizi. Jakarta (ID) : PT Gramedia Pustaka Utama.

Denzin NK. 1978. The Research Act: A Theoretical Introduction to Sociological Methods. New York (US). McGraw-Hill Book Company.

Gold SM.1980. Recreation Planning and Design. New York (US): Mc Graw-Hill Book Company.

Holmgren D. 2006. Permaculture: Solutions for Energy Descent [internet]. [Waktu dan tempat pertemuan tidak diketahui]. Melbourne (AU): Peak Oil and Permaculture Australian Tour Spring. hlm 1-10; [diunduh 2016 Nov 7]. Tersedia pada: https://holmgren.com.au/tag/peak-oil2/?v=3a1ed7090bfa.

Lakitan, B. 2002. Dasar-Dasar Klimatologi. PT. Raja Grafindo Persada. Jakarta.

Mollison B. 1993. The Permaculture Book of Ferment \& Human Nutrition. Tyalgum (AU): ATTRA Sustainable Agriculture.

Morrow R. 1993. Earth User's Guide To Permaculture. East Roseville (AU): Kangaroo Press.

Pahl-Wostl C, Rabbit H M. 2004. Processes of social learning in integrated resources management. Journal of Community and Applied Social Psychology. Osnabriick: 1 (14) 193-206.

Priandono A. 2006. Perancangan Kebun Produksi Berbasis LEISA untuk Pemenuhan Kebutuhan Gizi Sehat: Kasus Mahasiswa Asrama TPB-IPB [skripsi]. Bogor (ID): Institut Pertanian Bogor.
Raymond MC, Frantzeskaki N, Kabisch N, Pam B, Breil M, Razvan NM, Geneletti D, Calfapietra C. 2010. A framework for assessing and implementing the co-benefits of nature-based solutions in urban areas. Environmental Science and Policy. Clark University : (US).77 (2017) 15-24

Soekarno PWB. 2011. Pemaparan Rektor IPB pada Acara Rabuan Bersama IPB Tahun 2008-2010. Bogor (ID): IPB Press.

Studer R, Benjamins V, Fensel D. 1998. Knowledge engineering: principles and methods. Data and Knowledge Engineering Journal. 25 (1) 161-197.

[WHO] World Health Organization. 2007. Pengkategorian Status Gizi. Genewa (CH): WHO Technical Report Series. 